University of Nebraska - Lincoln

DigitalCommons@University of Nebraska - Lincoln

Nebraska Game and Parks Commission -- Staff

Research Publications

Nebraska Game and Parks Commission

$10-1980$

\title{
Epizootic of Coccidiosis in Free-Flying Lesser Scaup
}

R. M. Windingstad

National Wildlife Health Laboratory

M. E. McDonald

National Wildlife Health Laboratory

L. N. Locke

National Wildlife Health Laboratory

S. M. Kerr

National Wildlife Health Laboratory

J. A. Sinn

Nebraska Game and Parks Commission

Follow this and additional works at: https://digitalcommons.unl.edu/nebgamestaff

Part of the Environmental Sciences Commons

Windingstad, R. M.; McDonald, M. E.; Locke, L. N.; Kerr, S. M.; and Sinn, J. A., "Epizootic of Coccidiosis in Free-Flying Lesser Scaup" (1980). Nebraska Game and Parks Commission -- Staff Research Publications. 41.

https://digitalcommons.unl.edu/nebgamestaff/41

This Article is brought to you for free and open access by the Nebraska Game and Parks Commission at DigitalCommons@University of Nebraska - Lincoln. It has been accepted for inclusion in Nebraska Game and Parks Commission -- Staff Research Publications by an authorized administrator of DigitalCommons@University of Nebraska - Lincoln. 


\section{Case Report- \\ Epizootic of Coccidiosis in Free-Flying Lesser Scaup}

R. M. Windingstad, M. E. McDonald, L. N. Locke, S. M. Kerr

National Wildlife Health Laboratory

1655 Linden Drive

Madison, Wisconsin $\mathbf{5 3 7 0 6}$

and

J. A. Sinn

Nebraska Game and Parks Commission

2200 North 33rd Street

Lincoln, Nebraska 68503

Reprinted from Avian Diseases, Vol. 24, No. 4, October-December, 1980 
Case Report-

\title{
Epizootic of Coccidiosis in Free-Flying Lesser Scaup
}

\author{
R. M. Windingstad, M. E. McDonald, L. N. Locke, S. M. Kerr ${ }^{\mathbf{A}}$ \\ National Wildlife Health Laboratory \\ 1655 Linden Drive \\ Madison, Wisconsin 53706 \\ and \\ J. A. Sinn \\ Nebraska Game and Parks Commission \\ 2200 North 33rd Street \\ Lincoln, Nebraska 68503
}

Received 18 June 1979

\section{SUMMARY}

A coccidiosis epizootic has occurred in lesser scaup (Aythya affinis) at Bluestem Reservoir in eastern Nebraska during the spring in each of three recent years: 1976-1978. Losses peaked during the period from mid-March through April. As much as $29 \%$ of the peak population of scaup using the reservoir died. Necropsies of 72 of the nearly 1390 scaup that died revealed destruction and sloughing of the intestinal mucosa and associated hemorrhaging. Fibrinonecrotic cores were frequently found in the intestinal lumens. Scrapings from the intestinal mucosal contained massive numbers of oocysts of the coccidian Eimeria aythyae. This is the first report of recurrent epizootics of coccidiosis in freeflying waterfowl.

\section{INTRODUCTION}

Coccidiosis has been recognized as a disease of domestic poultry and game birds raised in captivity (2) and has also been reported in free-flying waterfowl (3), although not in epizootic forms. Eimeria, the genus of coccidia commonly found in anseriformes, are considered host-specific. Lesser scaup (Aythya affinis) are known to harbor $E$. aythyae in their intestinal tracts. Farr (1) believed that this organism was responsible for earlier die-offs that occurred in southern Wisconsin, Illinois, and Iowa.

A contribution from the U.S. Fish and Wildlife Service Project 1210903.02 and the Nebraska Game and Parks Commission. 69341 .

${ }^{A}$ Present address: Veterinary Clinic, P.O. Box 327, Gering, Nebraska 
This paper describes the recurring epizootics of coccidiosis at Bluestem Reservoir, near Lincoln, in Lancaster County, Nebraska.

Bluestem Reservoir is one of several reservoirs constructed for flood control and soil conservation in eastern Nebraska by the U.S. Army Corps of Engineers in the early 1960's. The reservoir covers 128 ha when full, has an average depth of $2.9 \mathrm{~m}$, is maintained by drainage from agriculture and pasture land, and freezes over each winter.

Lesser scaup are the primary waterfowl users of the Bluestem Reservoir. Peak spring numbers reach about 3,000 birds. Other waterfowl that use the reservoir include canvasback, Aythya valisineria; ruddy duck, Oxyura jamaicensis; green-winged teal, Anas crecca; bluewinged teal, Anas discors ; ring-neck, Aythya collaris; gadwall, Anas strepera; redhead, Aythya americana; and coot, Fulica americana.

\section{MATERIALS AND METHODS}

Dead birds were retrieved by boat, by all-terrain vehicle, or on foot. Seventy-two fresh carcasses were sent on wet ice to the National Wildlife Health Laboratory (NWHL) in Madison, Wisconsin, during the 3 years. In most instances, necropsies were performed within 24 hours after the birds arrived at the Laboratory, and samples were taken for bacterial, fungal, and viral examination or chemical analysis. Intestinal mucosal scrapings were examined microscopically. Fecal matter and the intestinal scrapings were placed in $2.5 \%$ potassium dichromate and allowed to sporulate for microscopic examination. Histological sections were prepared for examination for pathological lesions, using hematoxylin and eosin stains.

Bacteria obtained on routine cultures from liver and intestinal tissues were identified by the use of differential media. Appropriate tissue samples were tested for avian influenza virus, Newcastle disease virus, and duck plague virus, using egg-inoculation and tissue-culture techniques. Livers were examined by mass spectrometry for the presence of lead levels.

\section{RESULTS}

Notification of dead lesser scaup on Bluestem Reservoir was first received in March 1976. On 19 March 1976, one of us (JS) conducted a field investigation and recovered 90 dead lesser scaup and 2 dead canvasbacks. A total of 332 dead lesser scaup were re- 
Table 1. Known spring losses of lesser scaup at Bluestem Reservoir, Nebraska (1976-78).

\begin{tabular}{lrccc}
\hline Year & $\begin{array}{c}\text { Known } \\
\text { dead }\end{array}$ & $\begin{array}{c}\text { No. Scaup } \\
\text { examined }\end{array}$ & $\begin{array}{c}\text { Water } \\
\text { coverage (ha) }\end{array}$ & $\begin{array}{c}\text { Date of } \\
\text { first deaths }\end{array}$ \\
\hline 1976 & 332 & 39 & 100 & 19 March \\
1977 & 898 & 17 & 80 & 6 Apri \\
1978 & 158 & 16 & 128 & 10 Apri1 \\
Total & 1388 & 72 & & \\
\hline
\end{tabular}

covered from the reservoir during that spring. Water levels at that time were considered to be below normal, covering about 100 ha (Table 1). In 1977 water levels were even lower: the reservoir covered only about 80 ha in the early spring. The first dead birds appeared on 6 April, when 143 dead scaup were retrieved; 898 had been recovered by the end of spring migration. The first mortalities in 1978 were recovered on 10 April, when eight scaup were found. Only 158 dead scaup were collected during the spring. Water levels in the reservoir were higher than normal.

The NWHL staff necropsied 72 of the 1388 lesser scaup found dead during the springs of 1976, 1977, and 1978. Coccidiosis was diagnosed as the cause of death. The most frequent gross lesions were epithelial destruction and sloughing of the intestinal mucosa, and associated hemorrhaging. Seldom was the entire intestine affected and no particular segment of intestine was consistently damaged. Often the small intestine was swollen and hyperemic, and had a hemorrhagic enteritis through much of its length. When the large intestine was involved, it was distended and hemorrhagic and had reddish-brown exudate in the lumen. Occasionally the mucosa of the duodenum was spotted with white areas $2-3 \mathrm{~mm}$ in diameter. Fibrinonecrotic cores, which were frequently found in the intestinal lumen, contained massive numbers of Eimeria oocysts. Development of 4 sporocysts upon sporulation, and characterization of the micropyles in addition to the measurements, indicate that this coccidian was Eimeria aythyae. The average oocyst measured was $20.4 \times 16.4 \mu$, compared with Farr's (1) original description of this species as $20.1 \times 15.5 \mu$. Wet mounts of intestinal mucosal scrapings also contained extremely high numbers of these oocysts. 
Histological sections of the intestine revealed large schizonts in the crypts of Lieberkuhn and merozoites in the tunica propria (Fig. 1) ; the villi epithelium and villi corium appeared necrotic. Typical macro- and micro-gametocytes were found in several sections (Fig. 2). A detailed description of these developmental stages of $E$. aythyae will be published elsewhere.

Three ring-necked ducks and 2 canvasback (also in the genus Aythyae) that were sent to the Laboratory from the Bluestem Reservoir were diagnosed as having coccidiosis. A few E. aythyaelike oocysts were found in each of the three ringnecks.

Routine bacterial cultures from tissues of 28 scaup yielded no consistently occurring pathogenic bacteria. Eleven of the 28 yielded no significant growth on either blood agar or eosin-methylene-blue agar. Primary isolations from the other were Escherichia coli, Enterobacter sp., and Citrobacter sp., and one isolation each of Aeromonas schigelloides and Bacillus sp.

Aspergillus sp. was isolated from 3 of the scaup necropsied, but it was considered to be a secondary invader.

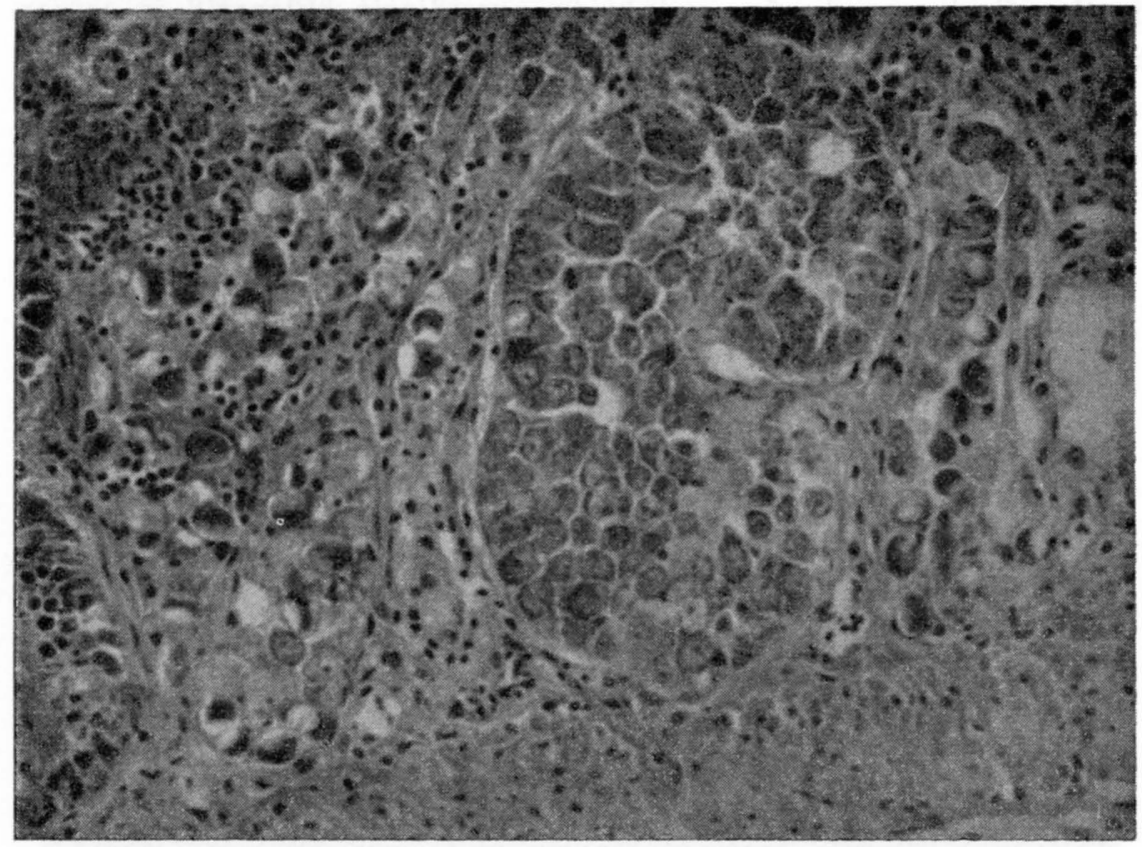

Fig. 1. Eimeria aythyae schizonts and early oocysts in intestinal crypts of a lesser scaup. $H \&$ E stain; $\times 380$. 
No Newcastle disease virus, avian influenza virus, or duck plague virus was isolated from the 16 scaup examined for these pathogens.

Lead concentratiors in 47 of the 48 livers examined ranged from undetectable to $5.6 \mathrm{ppm}$ dry weight; in 35 the levels were less than $0.1 \mathrm{ppm}$. In the one remaining liver, the lead concentration was $11.8 \mathrm{ppm}$ wet weight, a level that could be considered lethal; however, no gross pathological lesions suggestive of leadpoisoning were observed in this bird.

Preliminary findings suggest that female lesser scaup were more susceptible to coccidiosis that were males. Of 284 scaup counted on the reservoir in April 1978, 60\% were males; however, males made up only $38 \%$ of the 158 scaup that died that spring. Additional study is needed to determine if this is a chance event or reflects biological differences.

\section{DISCUSSION}

Although coccidia are commonly found in fecal samples of waterfowl, they rarely cause mortality in free-flying hosts. This is the first report of a recurring coccidiosis epizootic in lesser scaup or any other wild waterfowl. These epizootics were first

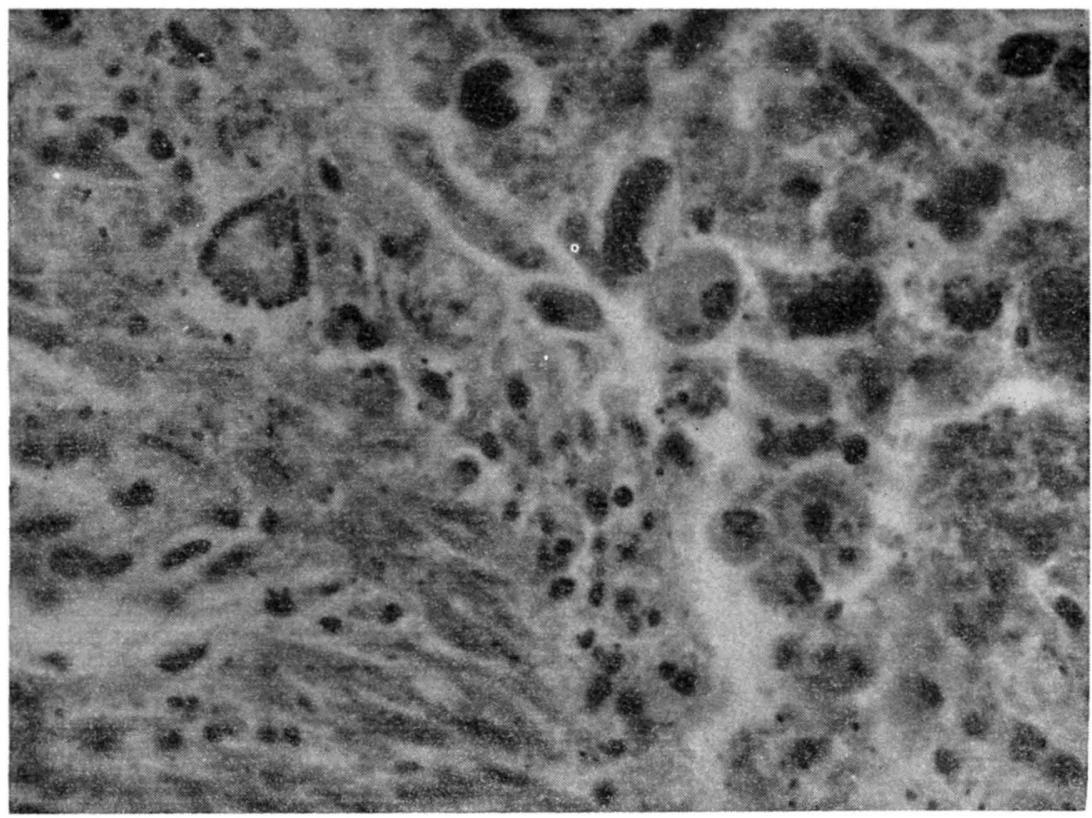

Fig. 2. Intestinal section of lesser scaup showing an Eimeria aythyae macrogametocyte and early oocysts. $H$ \& E stain; $\times 960$. 
noticed at Bluestem Reservoir in mid-March 1976 and also occurred there in the springs of 1977 and 1978, lasting from March through mid-May. Water levels in the reservoir may be an important factor, because losses werc highest in 1977, when the reservoir water level was the lowest. Losses were the lowest in 1978 (82\% less than in 1977), the year the reservoir water level was highest (Table 1). A more detailed study is needed to determine whether a relationship exists between water levels and total losses.

Bluestem Reservoir was constructed for flood control and soil conservation, along with several other similar reservoirs in this water-shed. Additional information is needed to determine why coccidiosis has been a problem at this reservoir and not at the others nearby that are also used by scaup. This information might help managers prevent the development of other reservoirs that may later serve as focal points for coccidiosis infection.

\section{REFERENCES}

1. Farr, M. M. Coccidiosis of the lesser scaup duck, Aythya affinis (Eyton, 1838), with a description of a new species, Eimeria aythyae. Proc. Helminthol. Soc. Wash. D.C. 32:236-238. 1965.

2. Reid, W. M. Coccidiosis. In: Diseases of poultry. M. S. Hofstad, B. W. Calnek, C. F. Humboldt, W. M. Reid, and H. W. Yoder, Jr., eds. pp. 784-815. lowa State University Press, Ames, Iowa. 1978.

3. Todd, K. S., Jr., and D. M. Hammond. Coccidia. In: Infectious and parasitic diseases of wild birds. J. W. Davis, R. C. Anderson, L. Karstad, and D. O. Trainer, eds. pp. 234-271. Iowa State University Press, Ames, Iowa. 1972 .

\section{ACKNOWLEDGMENTS}

The authors thank D. Docherty, R. Duncan, and D. Zoromanski for their valuable assistance and J. Runningen for the photography.

The field work for this publication was done by J. A. Sinn, who lost his life in a plane crash in 1979 while conducting a routine deer census. Without his contribution and dedication this paper would not have been completed. 